\title{
Herbicide-Free Technology for Suppressing Weeds on the Crops of Late-Ripening Maize in the Kabardino-Balkaria Steppe Zone
}

\section{Hasan Sh. Tarchokov¹, Dzhuleta A. Tutukova1, and Ruslan M. Dugarliev²}

${ }^{1}$ Field Crop Technology Laboratory, Institute of Agriculture - a branch of the Federal State Budget Scientific Institution Federal State Budgetary Scientific Institution Federal Scientific Center "Kabardino-Balkarian Scientific Center of the Russian Academy of Sciences" (Institute of Agricultural Sciences, KBSC RAS), Nalchik, Russian Federation

${ }^{2}$ Scientific and Educational Center of the Federal State Budgetary Scientific Institution "Federal Scientific Center" Kabardino-Balkaria Scientific Center of the Russian Academy of Sciences" (KBSC RAS), Nalchik, Russian Federation

\section{ORCID:}

Hasan Sh. Tarchokov: http://orcid.org/0000-0002-6187-7354

\section{Abstract}

As a result of multi-year research (2015-2017) of effective care techniques in the

Corresponding Author: Hasan Sh. Tarchokov kbniish2007@yandex.ru

Published: 5 April 2021

Publishing services provided by Knowledge E

(c) Hasan Sh. Tarchokov et al. This article is distributed under the terms of the which permits unrestricted use and redistribution provided that the original author and source are credited.

Selection and Peer-review under the responsibility of the DonAgro Conference Committee. post-sowing periods, the authors have concluded that it is possible to avoid the expensive use of herbicides to fight weeds of cultivated maize hybrids. Thus when a post-sowing packaging of ZKVG-1.4 was used; inter-row treatments with KRN-5.6 was carried out, additionally equipped with plowshares (sprinkling weeds in protective zones); harrows were weeded (effective combing in the area of crop rows); and irrigation furrows were cut with a ditch-furrow cutter, there was a $75.3-78.9 \%$ reduction in weeds, compared with a 78.5-84.3\% reduction when chemical weeding was used. This saved up to $0.4 \mathrm{t} / \mathrm{ha}$ of Kabardinskaya-3812 and Mashuk-480 SV and up to 0.5 t/ha Krasnodar-620 MV from losses. When weeds were removed manually during the growing season as they appeared on the maize hybrid crops, an average of 0.4-0.6 $\mathrm{t} / \mathrm{ha}$ were saved. Therefore, there is no need to use expensive herbicides for the crops of maize hybrids Mashuk-480 SV, Krasnodar-620 MV and Kabardinskaya-3812 in the fight against juvenile gramineous bilobated weed infestations. According to the results of our research, a significant alternative is the technologically competent use of all elements of agricultural technology with the obligatory consideration of the species composition of the weeds in each area. In addition, in Kabardino-Balkaria, the irrigated wedge accounts for only 130.7 thousand hectares of arable land out of the total sown area (286.8 thousand hectares). In the Republic, the main areas sown with maize are located on irrigated lands where the biological potential of this crop is realized to the greatest extent. However, it is on irrigated lands that weeds harm the maize crop the most. Therefore, the problem of protecting crops from weeds using cheaper methods for irrigation remains urgent.

Keywords: herbicides, weeds, vegetation period, manual weeding, grain productivity, crops harrowing, soil packing 


\section{Introduction}

In modern adaptive-landscape farming systems forming scientifically grounded and stable efficiency in combination with the environmental safety of the relevant products, the problem of suppressing weeds as well as protecting plants from pests and diseases is of great importance. At the same time, the main goal of this task is considered to be not their final extermination (otherwise, such a phenomenon can be attributed to the concept of barbarism towards nature) but reduction of their number in agrophytocenoses to a practically harmless level [1].

It should be noted that the known features of varieties and hybrids of agricultural crops play an essential role (intensive growth and development, large aboveground mass, etc.) in the fight against weeds. For example, the problem of weediness of some maize parents crops with an insignificant leaf mass compared to powerful plants hybrids intensifies since their small aboveground mass is less competitive regarding the weedfield community [2].

In domestic agricultural practice, some methods of minimizing soil cultivation in technologies of direct basic field crops sowing leading to an increase in weediness of cenoses and the need to use herbicides also remain problematic [3, 4].

\section{Conditions and Methods of Research}

The research was conducted in the period 2015-2017 in a stationary crop rotation located on the experimental field of the laboratory of technology for cultivating field crops (Tersky district, settlement Opytny).

The soil of the experimental area is an ordinary (carbonate) chernozem of heavy loamy granulometric composition. The arable layer $(0-20 \mathrm{~cm})$ contained 3.0-3.5 of humus, 0.140.27 of $\mathrm{P}_{2} \mathrm{O}_{5}, 2.0-2.6 \%$ of $\mathrm{K}_{2} \mathrm{O}$ (according to Machigin), 6.8-7.0 units $\mathrm{PH}$ with an average annual precipitation of $360-400 \mathrm{~mm}$.

During the research years, the weather conditions slightly differed from the average long-term indicators (Table 1).

The amount of precipitation in 2016 exceeded the average long-term (norm) data by $216.7 \mathrm{~mm}$, and in 2015 and 2017 it did not reach the norm by 88.1 and $60.9 \mathrm{~mm}$. The average air temperature was also higher by $0.9-3.6^{\circ} \mathrm{C}$ during the years of research. The relative air humidity was at the level of $70.3-73.8 \%$ against the long-term average of $76.9 \%$. 
TABLE 1: Meteorological indicators for the years of research (according to the agrometeorological post "Kuyan", settlement Opytny, Tersky district, Kabardino-Balkaria)

Year
2015
2016
2017
$\begin{aligned} & \text { Average long-term } \\ & \text { data (norm) }\end{aligned}$

\begin{tabular}{|c|}
\hline Precipitation, $\mathrm{mm}$ \\
\hline 382.9 \\
\hline 687.7 \\
410.1 \\
471.0 \\
\hline
\end{tabular}

\begin{tabular}{|c|}
\hline Air temperature, ${ }^{\circ} \mathrm{C}$ \\
\hline 12.6 \\
\hline 14.0 \\
\hline 11.3 \\
\hline 10.4 \\
\hline
\end{tabular}

\begin{tabular}{|c|}
\hline Relative humidity, \% \\
\hline 70.3 \\
\hline 72.6 \\
73.8 \\
76.9 \\
\hline
\end{tabular}

During the growing season, three furrow irrigations were carried out with a total irrigation rate of $1,230 \mathrm{~m}^{3} / \mathrm{ha}$.

In the experiments, hybrids of various originators being in the widest demand among land users of Kabardino-Balkaria were sown.

1. Hybrid population Kabardinskaya-3812 (originator is the Institute of Agriculture of the Kabardino-Balkarian Scientific Center of the Russian Academy of Sciences), late ripening (FAO-600) with a growing season of 140 days. The plant is tall (380$490 \mathrm{~cm}$ ), the stem is powerful, moderately resistant to lodging, folious. The height of the upper ear attachment is $125 \mathrm{~cm}$. The ear is cylindrical, large, $32-35 \mathrm{~cm}$ long, with the weight of $350-400 \mathrm{~g}$ and $16-18$ grain rows. The grain yield during threshing is $80-82 \%$ and the mass of 100 grains is $350-370 \mathrm{~g}$.

On a high agricultural background with irrigation, the yield of dry grain reaches 7.5-8.5 t/ha, green mass with cobs in the phase of milky-wax ripeness is 80.0-95.0 t/ha, stand density for harvesting recommended by the originator is 35.0 thousand per hectare of plants.

It is recommended for being cultivated for silage in the following republics: Kabardino-Balkaria, North Ossetia-Alania, Chechnya, Ingushetia, Dagestan, Stavropol Krai, Rostov, Voronezh, Kursk, Tambov, Belgorod and Lipetsk Oblast.

2. Mashuk-480 SV (originator is All-Russia Research Institute of maize) is a highyielding, medium late (FAO - 480) three-line hybrid of universal use for the North Caucasus region of the Russian Federation. Plant height is $240-250 \mathrm{~cm}$, ear attachment is $95-100 \mathrm{~cm}$, number of grain rows is $16-18$ with a tooth-shaped grain type and yellow color; conical ear is $19-22 \mathrm{~cm}$ long.

The hybrid is drought-resistant and resistant to stem rot, blistery and dusty head, and fusarium on the cob. It is distinguished by high strength of the stem. The recommended plant density for harvesting on dry land is 45-50, while on irrigation it is 60 thousand plants per hectare. 
It is preferable to use this hybrid in irrigated areas since it produces high grain yields, specifically, 7.5-7.9 t/ha, which exceeds the standard (Eric) by 0.45 t/ha. The commercial value of the hybrid is in its high yield, high growth, exceptional uniformity, excellent presentation, resistance to major diseases and pests.

3. Krasnodar-620MV is a late-ripening hybrid (FAO-600) (originator is the Krasnodar Research Institute of Agriculture). Seed is grown on a sterile "M" type CMS basis according to the full recovery scheme.

Parental forms on the hybridization areas are sown at one time according to the 12:4 scheme, the rows of paternal plants are mown after panicle flowering. It is zoned for grain production in areas of sufficient moisture in the Lower Volga region, the North Caucasus and is used both for grain and silage. It is a double interline hybrid with a vegetation period of 130-134 days, stem height of $275-280 \mathrm{~cm}$ and it is not bushy.

Ears are attached to the stem at a height of $100-110 \mathrm{~cm}$, have a cylindrical shape and are $22 \mathrm{~cm}$ long with the number of grain rows equal to $45-47$, the grain yield during threshing equal to $80 \%$, the weight of 1000 grains being $280-290 \mathrm{~g}$.

The cob core is red, has drought resistance, grain yield can reach more than 10.0 $\mathrm{t} / \mathrm{ha}$ and silage mass is up to $4.5 \mathrm{t} / \mathrm{ha}$.

Maize hybrids were grown in a short (three-field) rotation with the following crop alternation: maize - winter wheat - peas for grain.

In the option with the use of chemical treatment in the fight against weeds, Lumax, SE $(375+125+37.5 \mathrm{~g} / \mathrm{l})$ produced by "Syngenta" was applied at a dose of $3.5 \mathrm{l} / \mathrm{ha}$ using a shoulder sprayer before crop emergence under "blind" harrowing (2-3 days before germination).

The technology of irrigated maize cultivation for grain is generally accepted for this zone of the republic. Most of mineral fertilizers (N30 P90 K60) were introduced in autumn for the main tillage. Ammonium nitrate at a rate of application equal to $30 \mathrm{~kg} / \mathrm{ha}$ and in the form of top dressing was introduced at the phase of 3-5 leaves of maize. Irrigation was designated at $70 \%$ moisture content of the PPV of $0-60 \mathrm{~cm}$ of the soil layer and was carried out manually along furrows.

The research studied the techniques of caring for crops (factor A) of maize:

1. Control-1 (economic);

2. Control-2 (without weeds), where weeds were removed by hand as long as they grew in the weeding area during the growing season of maize; 
3. Lumax, SE $(375+125+37.5 \mathrm{~g} / \mathrm{l}), 3.5 \mathrm{l} / \mathrm{ha}$;

4. Harrowing of crops: $1^{\text {st }}$ following maize crops; $2^{\text {nd }} 2-3$ days ("blind") before the emergence of crop shoots;

5. Rolling of crops ZKVG t-1.4 after the $1^{\text {st }}$ harrowing $+2^{\text {nd }}$ harrowing $2-3$ days ("blind") before the emergence of crop shoots.

Surveys of maize crops have identified over 18 weed species belonging to various botanical families. Certain types of perennial weeds (Cuba grass, sow thistles, field bindweed) growing in small beds were also removed manually [5].

The main goal of our research was to assess the impact of agricultural practices, use of chemical weeding (herbicide) and manual weeding on the weed infestation of maize hybrids of various originators in the steppe zones of Kabardino-Balkaria.

The experiments were carried out by the field method in 4 -fold repetition by the systematic method in two tiers. The areas of the plots were as follows: $150 \mathrm{~m}^{2}$ totally, $120 \mathrm{~m}^{2}$ of registration plot, the crops weediness were counted twice by the quantitativeweight method during the period of full germination of the crop (quantitative) and before harvesting grain (quantitative-weight). Grain yield was accounted by the method of manual breaking of the plots accounting area with subsequent conversion to t/ha of standard grain moisture, economic efficiency was calculated in accordance with the guidelines for determining the economic efficiency of using scientific developments in agriculture [6].

\section{Research Results}

According to a number of authors [7], under the conditions of rising prices for energy sources and chemicals (including herbicides), the use of intensive technologies for agricultural crops cultivation is difficult, and for many farms it is very problematic. Therefore, the issues of finding resource conservation ways in the appropriate agricultural technologies are of particular importance $[8,9]$.

As can be seen from the results of our research (Table 2), the maximum number of weeds (208-215 specimens per $\mathrm{m}^{2}$ of crops) was noted during the period of full crop emergence. However, by the period under review, the use of the herbicide Lumax, SE at a dose of $3.5 \mathrm{I} /$ ha reduced the contamination of crops in the hybrid population of Kabardinskaya-3812 and Mashuk-480 SV by 80.3 and $80.0 \%$. With regards to Krasnodar$620 \mathrm{MV}$ hybrid it reduced by $76.0 \%$. The technical efficiency of harrowing crops is somewhat lower, while weeds were suppressed by only $69.2-72.5 \%$ in comparison with 
economic control. At the same time, the efficiency of harrowing crops in the fight against weeds increases sharply when the technique is implemented against the background of rolling post-sowing soil with smooth water-filled rollers ZKVG-1.4, specifically, up to 74.6-79.3\% of their death on the crops of the tested hybrids. In this case, the effect of rolling crops (through improving the contact of weed seeds with the soil) is more aimed at ensuring the mass germination of weeds in the $0-5 \mathrm{~cm}$ soil layer. In this soil layer obtaining certain biological characteristics, the bulk of the young weed-field community is located in the agrocenoses of the main row crops of the steppe zone of Kabardino-Balkaria, including maize.

By the end of the maize hybrids growing season, an increase in the technical efficiency of agro-technological methods is facilitated by the powerful above-ground mass of crop hybrids, for which it no longer presents "serious" competition from the shoots of the next wave of weakened, exhausted weeds growing in the lower layer of maize.

Our studies have determine the quantitative and weight composition of weeds on maize crops, where chemical weeding reduces the weediness of cenoses for Kabardinskaya-3812 and Krasnodar- $620 \mathrm{MV}$ by 84.3 and $78.5 \%$ by quantity and with a slight air-dry weighing 18.0 and $17.0 \mathrm{~g} / \mathrm{m}^{2}$, respectively. For the crops of the Mashuk480SV hybrid, these indicators were at the level of 82.1 by quantity and $15.0 \mathrm{~g} / \mathrm{m}^{2}$ by weight. With regards to agrotechnical methods of weed control, the same results were achieved as against the background of chemical weeding of corn crops.

Different degrees of weed infestation of crops in our studies influenced the formation of grain productivity of maize hybrids (Table 3 ).

TABLE 2: Influence of care techniques on the yield ( $t /$ ha St moisture) of grain of various maize hybrids (average for 2015-2017)

\begin{tabular}{|c|c|}
\hline No. & Care techniques (factor $\mathrm{A}$ ) \\
\hline 1. & Control-1 \\
\hline 2. & Control-2 \\
\hline 3. & Lumax, SE - 3.5 I/ha \\
\hline 4. & $\begin{array}{l}\text { Harrowing of crops: } 1^{\text {st }} \text { at } 2^{\text {nd }}-3^{\text {rd }} \text { day } \\
\text { before germination; } 2^{\text {nd }} \text { at the phase } \\
3-5 \text { leaves of maize }\end{array}$ \\
\hline \multirow[t]{2}{*}{5.} & Rolling of crops ZKVG-1.4 + option 4 \\
\hline & NSR - t/ha \\
\hline
\end{tabular}

\begin{tabular}{|c|c|c|c|c|c|}
\hline $\begin{array}{c}\text { Kabardinskaya- } \\
3812 \text { (factor } \\
\text { B) }\end{array}$ & \multicolumn{2}{|c|}{$\begin{array}{c}\text { Mashuk-480SV } \\
\text { (factor B) }\end{array}$} & \multicolumn{2}{|c|}{$\begin{array}{c}\text { Krasnodar-620MV } \\
\text { (factor B) }\end{array}$} \\
\hline totally & $\begin{array}{c}\text { saved } \\
\text { crop }\end{array}$ & totally & $\begin{array}{c}\text { saved } \\
\text { crop }\end{array}$ & totally & $\begin{array}{c}\text { saved } \\
\text { crop }\end{array}$ \\
\hline 5.2 & - & 4.5 & - & 5.0 & - \\
\hline 6.7 & +1.5 & 6.0 & +1.5 & 6.6 & +1.6 \\
\hline 6.6 & +1.4 & 5.2 & +0.7 & 6.5 & +1.5 \\
\hline 6.4 & +1.2 & 5.7 & +1.2 & 6.0 & +1.0 \\
\hline 6.6 & +1.4 & 5.0 & +0.5 & 6.3 & +1.3 \\
\hline- & 0.15 & - & 0.10 & - & 0.13 \\
\hline
\end{tabular}

Thus, the grain productivity of Kabardinskaya-3812 and Krasnodar-620MV was at the level of 5.2 and 5.0 t/ha on economic control. 
TABLE 3: Effectiveness techniques aimed to cope with weeds on crops of various maize hybrids in KabardinoBalkaria steppe zone (Number of weeds per $1 \mathrm{~m}^{2}$ )

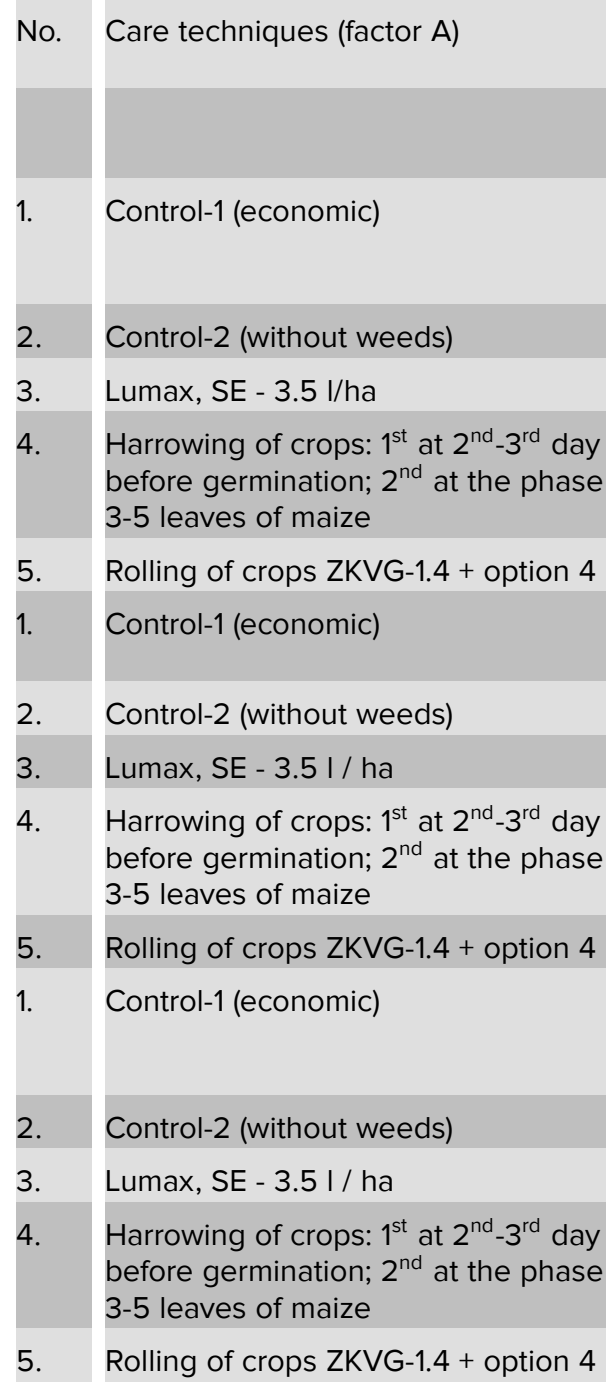

\begin{tabular}{|c|c|c|c|c|c|}
\hline \multirow{2}{*}{$\begin{array}{l}\text { Hybrids } \\
\text { (factor } \mathrm{B} \text { ) }\end{array}$} & \multicolumn{2}{|c|}{ Full crop shoots } & \multicolumn{3}{|c|}{ Before harvesting grain } \\
\hline & $\begin{array}{l}\text { total, } \\
\text { pcs. }\end{array}$ & $\%$ death & $\begin{array}{l}\text { total, } \\
\text { pcs. }\end{array}$ & $\%$ death & weight, g \\
\hline \multirow{5}{*}{$\begin{array}{c}\text { Kabard- } \\
\text { inskaya- } \\
3812\end{array}$} & 208 & - & 89 & - & 139.5 \\
\hline & 214 & 100 & - & 100 & - \\
\hline & 41 & 80.3 & 14 & 84.3 & 18.0 \\
\hline & 61 & 70.6 & 25 & 71.9 & 37.5 \\
\hline & 43 & 79.3 & 16 & 82.0 & 20.5 \\
\hline \multirow{5}{*}{$\begin{array}{l}\text { Mashuk- } \\
480 \mathrm{SV}\end{array}$} & 215 & - & 95 & - & 195.0 \\
\hline & 213 & 100 & - & 100 & - \\
\hline & 43 & 80.0 & 17 & 82.1 & 15.0 \\
\hline & 59 & 72.5 & 28 & 70.5 & 38.4 \\
\hline & 51 & 76.3 & 20 & 78.9 & 23.0 \\
\hline \multirow{5}{*}{$\begin{array}{c}\text { Krasno- } \\
\text { dar- } \\
620 \mathrm{MV}\end{array}$} & 209 & - & 93 & - & 160.0 \\
\hline & 215 & 100 & - & 100 & - \\
\hline & 50 & 76.0 & 20 & 78.5 & 17.0 \\
\hline & 64 & 69.2 & 36 & 61.3 & 28.4 \\
\hline & 53 & 74.6 & 18 & 80.6 & 20.4 \\
\hline
\end{tabular}

Removing weeds manually during the growing season increased these indicators for hybrids by 1.5-1.6 t/ha on average. Regarding the options with the use of chemical weeding, the amount of the preserved grain yield by hybrids ranged from $1.4 \mathrm{t} / \mathrm{ha}$ (Kabardinskaya-3812) to 0.7-1.5 t/ha (Mashuk-480SV and Krasnodar-620MV). The economic efficiency of harrowing crops of Kabardinskaya-3812 and Krasnodar 620MV in terms of the level of additional grain production of hybrids (factor B) is slightly lower (1.2-1.0 $\mathrm{t} / \mathrm{ha}$ ) than the data of the herbicide background of weed suppression but they are within limits the experimental error. However, the use of this agricultural technique becomes more effective when it is carried out against the background of rolling crops with preservation from losses of up to 1.4 and 1.3 t/ha for Kabardinskaya-3812 and Krasnodar-620MV. As for Mashuk-480SV, these indicators are slightly lower (0.5 t/ha). 
Along with the above, it should be noted that modern agriculture is characterized by intensive consumption of known energy resources being electricity, fuel, fertilizers, herbicides, etc.

Due to the country's transition to a market economy and systematic changes in prices for certain materials and services, it is not possible to assess the efficiency of cultivation of a single crop, the use of a particular technological agricultural technique without calculating the costs and income from selling the produced goods [10].

In our research based on the data of the technological map of cultivating agricultural crops, production costs were determined on various backgrounds of cultivation methods using the example of a hybrid population of Kabardinskaya-3912. The grain yield was taken as the average for three years of research (Table 4).

TABLE 4: Economic efficiency of various care techniques on maize crops Kabardinskaya-3812 (average for 2015-2017)

\begin{tabular}{|c|c|c|c|c|c|c|}
\hline No. & Care techniques & $\begin{array}{l}\text { Grain } \\
\text { yield, } \\
\text { t/ha }\end{array}$ & $\begin{array}{l}\text { Gross } \\
\text { produc- } \\
\text { tion cost, } \\
\text { rubles } \\
\text { per } \\
\text { hectare }\end{array}$ & $\begin{array}{l}\text { Production } \\
\text { costs, rubles } \\
\text { per hectare }\end{array}$ & $\begin{array}{l}\text { Net } \\
\text { profit, } \\
\text { rubles } \\
\text { per } \\
\text { hectare }\end{array}$ & Profitability, \% \\
\hline 1 & Control-1 & 5.2 & 62,400 & 40,300 & 22,100 & 55 \\
\hline 2 & Control-2 & 6.7 & 80,400 & 41,200 & 39,200 & 95 \\
\hline 3 & Lumax, SE - 3.5 I/ha & 6.6 & 79,200 & 42,700 & 36,500 & 85 \\
\hline 4 & $\begin{array}{l}\text { Harrowing before and after } \\
\text { sprouting }\left(1^{\text {st }} \text { at } 2^{\text {nd }}-3^{\text {rd }} \text { day before }\right. \\
\text { germination; } 2^{\text {nd }} \text { at the phase } 3-5 \\
\text { leaves of maize })\end{array}$ & 6.4 & 76,800 & 41,000 & 35,800 & 87 \\
\hline 5 & Rolling of crops ZKVG-1.4 + option 4 & 6.6 & 79,200 & 41,300 & 37,900 & 92 \\
\hline
\end{tabular}

The calculations have shown that the cost of gross maize grain production (market price of 12.0 rubles per $\mathrm{kg}$ for January $1^{\text {st }}, 2020$ ) under economic control (option 1 ) did not exceed 62,400 rubles per hectare. Excluding production costs, the net profit amounted to 22,100 rubles per hectare with a profitability level of $55 \%$. The complete elimination of the negative impact of the weeds on the productive process of the crop grain through manual removal during the growing season ensures the formation of grain products in the amount of 39,200 with a profitability level of $95 \%$, which is $10 \%$ higher than the indicators obtained against the background of chemical weeding of crops. However, the crops harrowing 2-3 days before emergence and in the phase of 3-5 leaves (postemergence harrowing) of maize against the background of post-sowing rolling of sown crop seeds contribute to the formation of a net profit equal to $35,800-37,900$ rubles per hectare. 


\section{Conclusion}

1. The calculations confirm that the cultivation of corn of the hybrid population of Kabardinskaya-3812 under irrigation conditions in the steppe zone of KabardinoBalkaria is economically profitable.

2. Calculations of the technical and economic efficiency of grain production for the Mashuk-480SV, Krasnodar-620MV hybrids and the Kabardinskaya-3812 hybrid population confirm that under the conditions of the juvenile gramineous bilobated type of weed infestation it is quite possible to avoid herbicides and hand weeding.

\section{References}

[1] Bazdyrev, G. I. (1999). Weed Control in Modern Farming Systems. Agriculture, vol. 2, p. 31.

[2] Tarchokov, K. S. (2014). Control of Weeds in Seed Maize Crops for Irrigation. Agriculture, vol. 5, pp. 37-39.

[3] Kiryushin, V. I. (2018). Tasks of Scientific and Innovative Support of Agriculture in Russia. Agriculture, vol. 3, pp. 3-8.

[4] Tarchokov, K. S. and Chochaev, M. M. (2013). Land Fund and Soil Resources of the KBR. Agriculture, vol. 8, pp. 7-10.

[5] Dospekhov, B. A. (1985). Field Experiment Technique. Moscow: Agropromizdat, p. 416.

[6] Tarchokov, K. S. (2017). Resource-Energy-Efficient Methods of Weed Suppression in Landscape Agriculture of the Kabardino-Balkarian Republic. In Sustainable Development: Problems, Concepts, Models. Nalchik: Kabardino-Balkar Scientific Center of the Russian Academy of Sciences

[7] Vislobokova, L. N., Sorochkin, Y. P. and Vorontsov, V. A. (2013). Agrotechnological Modernization of Agriculture. Kursk: GNU VNIIZiZPE.

[8] Tarchokov, K. S. and Chochaev, M. M. (2017). To Establish the Best Ways to Reduce Weeds on a Herbicide-Free Basis in Agrocenoses of the Main Field Crops. Moscow: Center for Information Technologies and Systems of Executive Authorities, p. 13.

[9] Pavlyushkin, V. A. and Hannibal, F. B. (2019). For Guaranteed Crop Protection and the Achievement of Environmental Safety in Agroecosystems. Plant Protection and Quarantine, vol. 10, pp. 3-10.

[10] Kiryushin, V. I. (2018). The Tasks of Scientific and Innovative Support of Agriculture in Russia. Agriculture, vol, 3, pp. 3-8. 